\title{
First Paleoparasitological Report on the Animal Feces of Bronze Age Excavated from Shahr-e Sukhteh, Iran
}

\author{
Mahsasadat Makki', Jean Dupouy-Camet², Seyed Mansour Seyed Sajjadi ${ }^{3}$, Saied Reza Naddaff', Iraj Mobedi', \\ Mostafa Rezaeian ${ }^{1,5}$, Mehdi Mohebali ${ }^{1,5}$, Gholamreza Mowlavi ${ }^{1,5, *}$ \\ ${ }^{1}$ Department of Parasitology and Mycology, School of Public Health, Tehran University of Medical Sciences, Tehran, Iran; 'ACMSFI, Hôpital Cochin, \\ 27 Faubourg St Jacques, 75014 Paris, France; 3Iranian Centre for Archaeological Research, Tehran, Iran; ${ }^{4}$ Department of Parasitology, Pasteur \\ Institute of Iran, 69 Pasteur Avenue, Tehran, Iran; ${ }^{5}$ Center for Research of Endemic Parasites of Iran (CREPI), Tehran University of Medical Sciences, \\ Tehran, Iran
}

\begin{abstract}
Shahr-e Sukhteh (meaning burnt city in Persian) in Iran is an archeological site dated back to around 3,2001,800 BC. It is located in Sistan and Baluchistan Province of Iran and known as the junction of Bronze Age trade routes crossing the Iranian plateau. It was appointed as current study area for paleoparasitological investigations. Excavations at this site have revealed various archeological materials since 1967. In the present study, sheep and carnivore coprolites excavated from this site were analyzed by means of rehydration technique using TSP solution for finding helminth eggs. Dicrocoelium dendriticum, Capillaria sp., and Taenia sp. eggs were identified, while some other objects similar to Anoplocephalidae and Toxocara spp. eggs were also retrieved from the samples but their measured parameters did not match those of these species. The present paper illustrates the first paleoparasitological findings of Bronze Age in eastern Iran supporting the economic activities, peopling, and communication as well as the appropriate condition for zoonotic helminthiasis life cycle in Shahr-e Sukhteh archeological site.
\end{abstract}

Key words: Dicrocoelium dendriticum, Capillaria sp., Taenia sp., egg, Bronze Age, Shahr-e Sukhteh, Iran

\section{INTRODUCTION}

Paleoparasitology is a new interdisciplinary line of research, for studying parasites of humans and animals in ancient communities. According to available documents, coprolites are regarded as potential biological remains for tracking ancient parasites worldwide [1]. Paleoparasitological studies elaborate some attractive subjects, including the geographical origin of the parasites, status of zoonotic diseases, types of diets, public health levels, and the occupations of the ancient people in the past $[2,3]$. Although the identification of zoonotic parasites is an important issue, documentation of veterinary parasites has its own eco-biological value. International papers released in this field of research reported several animal helminth eggs identified in coprolites, e.g., Trichuris, Capillaria, and Anoplocephalidae eggs in canid coprolites in Argentina [4], capillariids,

- Received 29 November 2016, revised 4 January 2017, accepted 15 January 2017

*Corresponding author (molaviva@tums.ac.ir; molavig@yahoo.com)

(c) 2017, Korean Society for Parasitology and Tropical Medicine

This is an Open Access article distributed under the terms of the Creative Commons Attribution Non-Commercial License (http://creativecommons.org/licenses/by-nc/4.0) which permits unrestricted non-commercial use, distribution, and reproduction in any

medium, provided the original work is properly cited. trichostrongylids, and taeniid eggs from Late Holocene in Patagonian human and/or canid coprolites [5]. In Iran, Chehrabad salt mine archeological site (500 AC) has recently provided the opportunity of analyzing well preserved coprolites of rats, carnivores, and horses to recover helminth eggs [6-8]. Shahr-e Sukhteh, of Bronze Age (3,200-1,800 BC) located in a desertic area of Sistan and Baluchistan Province in southeastern Iran is regarded as a representative source for ancient biological remains used in paleoparasitological studies in this part of the country. Concerning the land vastitude and population, the number of goat, sheep, and other domesticated animals in this territory in its prosperity time should have been high. These findings along with thematic analysis reflect a flourishing economic in this area community at Bronze Age [9]. In the present paper, helminth eggs of sheep and carnivores retrieved from the collected paleofeces are illustrated and discussed.

\section{MATERIALS AND METHODS}

\section{Archeological site}

Shahr-e Sukhteh is located in southeastern Iran $\left(30^{\circ} 39^{\prime} \mathrm{N}\right.$; $61^{\circ} 24^{\prime} \mathrm{E}$ ), bordering Afghanistan (Fig. 1). This is a vast area 
covering around $\approx 151$ ha and comprises 3 different districts (residential, cemetery, and industrial). The collection of animal paleofeces was performed in 3 occasions during 2014 and 2015. The whole coprolites of this study have been found in the residential area $[9,10]$.

\section{Specimens}

Thirty coprolites of sheep (code nos. 6, SDI2, SDI2, SDG2) and a small amount of carnivore excrement (code no. SDH3) were collected from the residential area of the site. The dating of the coprolites analyzed herein has been calculated using radiocarbon determination on the charcoal samples excavated from the relevant layers of coprolites [11]. For helminthological analyses, the samples were transferred to the Helminthology Laboratory at the School of Public Health, Tehran University of Medical Sciences, Tehran, Iran. Specimens were rehydrated in $0.5 \%$ aqueous trisodium phosphate (TSP) solution supplemented with $5 \%$ glycerin as described by others [12].

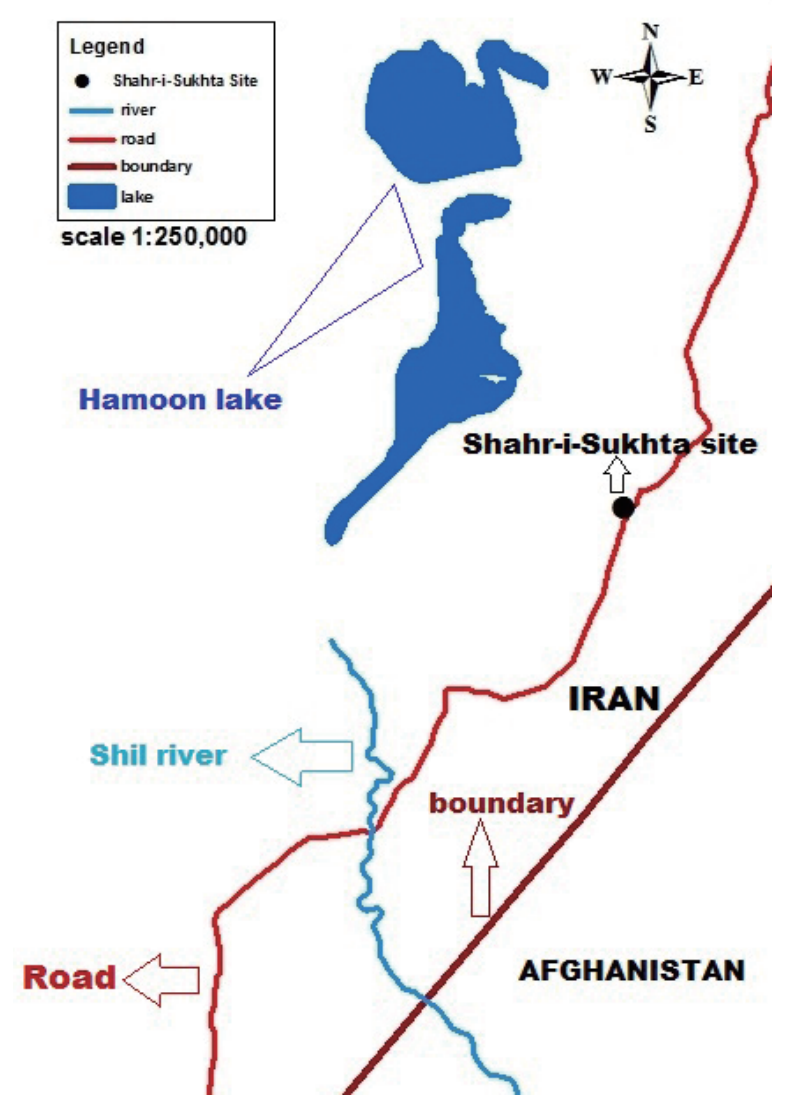

Fig. 1. Location of Shahr-e Sukhteh archeological site, Iran (with permission from Hossein Moradi).

\section{Egg identification}

Two weeks after rehydration, 50 slides from each processed coprolite were mounted in glycerin gel [7]. The slides were carefully examined under a light microscope with the magnification of $40 \times$ and $100 \times$ and photographed using a digital microscope camera (Labomed LX 500, Springfield, New Jersey, USA). The identification was based on morphological features and dimensions of the eggs reflected in reliable key references [13-15].

\section{RESULTS}

Out of 30 sheep paleofeces (Fig. 2) examined in this study, 3 of them were found parasitized. The analysis of 1 coprolite showed 3 eggs of Capillaria sp. (Fig. 3A-C) and 1 egg of Dicrocoelium dendriticum (Fig. 3F), while the next 2 paleofeces were each containing 1 taeniid egg (Fig. 3D, E). The size of eggs is shown in Table 1. Some other objects, similar to the eggs of Anoplocephalidae, were also detected in analyzed sheep samples, but their morphological details did not match the characteristics of the eggs of this family (Fig. 3G-I). This was also the case for some objects retrieved from the carnivore paleofeces as they were very similar to Toxocara spp. eggs, but their size was smaller than the reported values for this species (Fig. 3J).

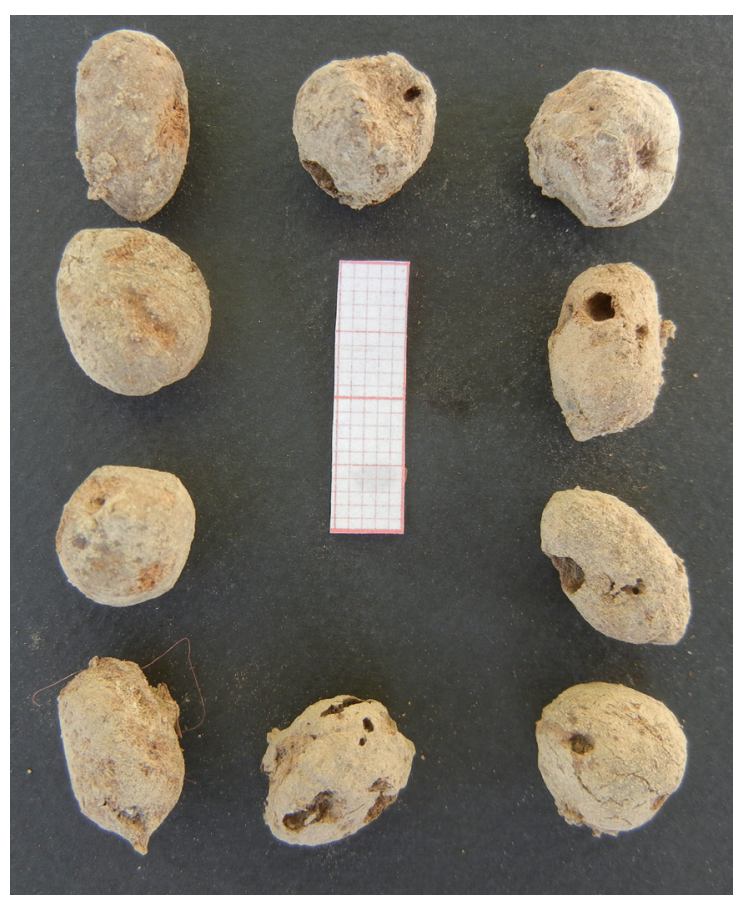

Fig. 2. Some sheep coprolites analyzed in this study. 

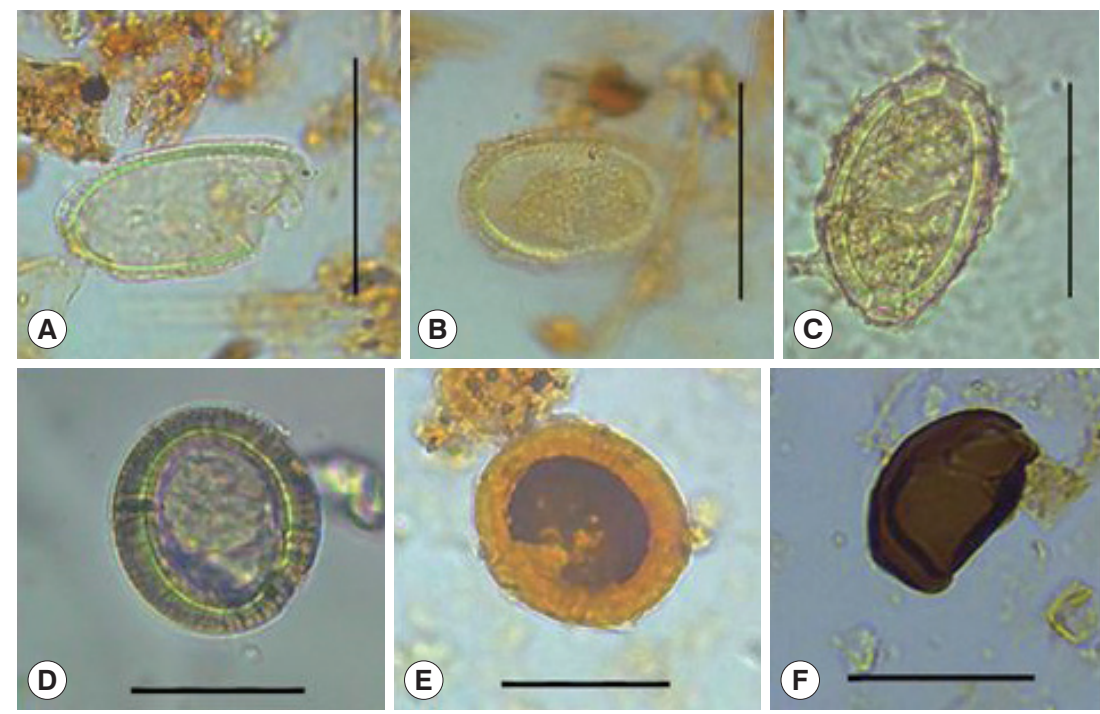

\section{(B)}
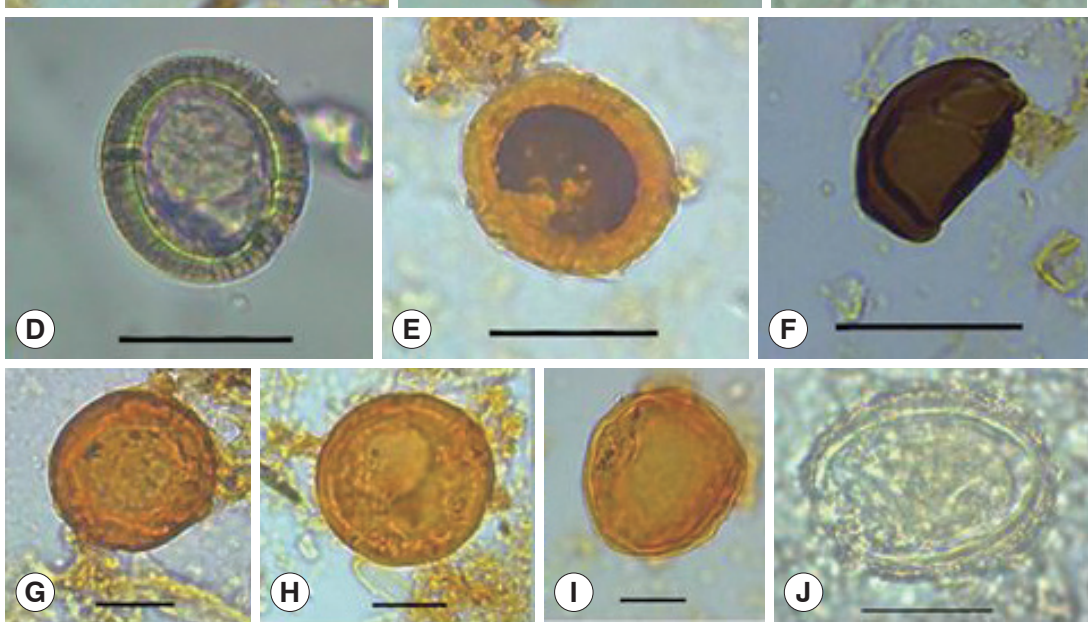

Fig. 3. The helminth eggs retrieved from paleofeces in Shahr-e Sukhteh, Iran. (A-C) Capillaria sp. eggs. (D, E) Taenia sp. eggs. (F) Dicrocoelium dendriticum egg. (G-I) Anoplocephalidae egg-like objects. (J) Toxocara spp. egg-like object. Scale bars: A-C, 50 um; D-F, 30 $\mu \mathrm{m} ; \mathrm{G}-\mathrm{J}, 20 \mu \mathrm{m})$.

Table 1. Measured sizes of helminth species retrieved from sheep paleofeces in Shahr-e Sukhteh, Iran

\begin{tabular}{lcc}
\hline Helminth eggs (no. of eggs) & Length $(\mu \mathrm{m})$ & Width $(\mu \mathrm{m})$ \\
\hline Capillaria sp. (3) & 59.8 & 35.5 \\
& 47.5 & 29.3 \\
& 54.8 & 27.5 \\
Dicrocoelium dendriticum (1) & 33.9 & 21.0 \\
Taenia sp. (2) & 38.5 & 36.2 \\
& 37.3 & 36.4 \\
\hline
\end{tabular}

\section{DISCUSSION}

Paleoparasitology has received significant attention in recent years and allows to compare the past and present status of parasitic infections and to predict their impact in future. Here, we report the finding of animal helminth eggs in coprolites from Shahr-e Sukhteh in southeastern Iran dating back to Bronze Age. D. dendriticum (the lancet liver fluke) egg found in the present study indicates the occurrence of this parasite at that time which may also drag the attention to human dicrocoeliasis in the ancient Shahr-e Sukhteh area. However, the emergence of zoonotic helminths like $D$. dendriticum has been in- terpreted earlier through finding of the eggs in animal coprolites in the far past [16].

The cestode eggs cannot be distinguished morphologically to the species level [17], so our finding of taeniid eggs can hardly be attributed to the occurrence of a particular zoonotic infection like echinococcosis. Recovering intact helminth eggs with characteristic features is not commonly expected in archeological sites due to taphonomic changes over an extended period. These possible morphological changes can be described for present Dicrocoelium egg with 1 side shrinkage despite its apparent morphology.

Various helminth eggs have been recovered from archeological sites in wetlands and marshes of Europe [18], which indicate the appropriate preservation condition in this continent over the past periods of time. Due to unfavorable climate conditions in most parts of Iran [19], these appropriate occasions might be rarely encountered in archeological sites in the country.

Recent archeological excavations in Iran have revealed few parasite eggs, e.g., only $1 \mathrm{D}$. dendriticum egg in the burial soil of a human grave of Bronze Age in Yasuj [20] and an Enterobius 
vermicularis egg from a human female skeleton dated back to 5,000 BC [21]. In Chehrabad salt-mine in northwestern Iran, dating back to around $500 \mathrm{BC}$ (Achaemenid Period) to 500 $\mathrm{AD}$ (Sassanid Era), more helminth eggs were recovered and successfully identified. Owing to high concentrations of salt in this archeological site, mummified bodies and human and animal paleofeces remained well-preserved. In this site, several parasitic helminth eggs were retrieved and identified, including Taenia sp. eggs in a mummified miner [22], various animal and human helminth eggs in soil samples [8], Macracanthorhynchus hirudinaceus eggs in canine paleofeces [7], and Trichosomoides crassicauda, Syphacia sp., and Trichuris sp. ova in rodent coprolites [6].

Archeological findings in Shahr-e Sukhteh have revealed that environmental condition in prehistorical time should have been more moderate than the present, due to flows of Helmand River and Hamoon Lake [22]. The presence of dicrocoeliasis may support this climatological conclusion. The eggs of $D$. dendriticum have been previously recovered from humans or animal paleofeces in other parts of the world, including Iran $[20,24]$. The above mentioned taeniid eggs in sheep coprolite with compatible size and outer layer striation is assumed as transitional eggs which might have been ingested while grazing.

Although taeniid eggs have been previously recovered from different biological remains as well as latrines, mixed sediments of human and animal excrements [16], finding of Taenia sp. eggs in sheep paleofeces, seems controversial, if transitional condition is not regarded. Recovery of Capillaria sp. eggs, most probably C. bovis or its newest synonyms C. brevipes and C. longipes [25], is worth mentioning since this helminth is not prevalent in paleoparasitological and modern reports worldwide. Due to taphonomic process, 1 of the Capilaria eggs found (Fig. 3C) was not the same as the other 2 typical eggs (Fig. 3A, B). Nevertheless, belonging of the egg to other trichuridae family, most presumably Trichuris sp., should be taken into account. Of note, C. brevipes still parasitizes sheep in Iran [26]. Regarding the rarity of this group of helminths in the country, mentioning the only occurrence of a human intestinal capillariasis due to C. philippiensis in 1987 is exemplary herein [27]. Capillariid parasites belonging to Neolithic time were also reported from France, where out of 23 collected human coprolites 21 were positive for eggs of these parasites [18].

The recovery of Anoplocephalan and Toxocara spp. eggs in this study can only be suspected in ancient Shahr-e Sukhteh, as the morphological characters and the measured parameters were not conclusive. To conclude, our study is the first to report parasitic helminths in animal coprolites from the Bronze Age in Shahr-e Sukhteh archeological site.

Extending the current investigation in forthcoming excavations with a special focusing on sampling in residential area may bring a deeper insight of the status of parasitic infections over that time.

\section{ACKNOWLEDGMENTS}

We are thankful to Iranian Center for Archeological Research (ICAR) for providing the facilities. We are also grateful to Hossein Moradi, Hossein Sarhaddi Dadian, Haleh Helali, and Gordon Langsley for their invaluable contribution to this work.

\section{CONFLICT OF INTEREST}

We have no conflict of interest related to this study.

\section{REFERENCES}

1. Araújo A, Ferreira LF. Paleoparasitology and the antiquity of human host-parasite relationships. Mem Inst Oswaldo Cruz 2000; 95: 89-93.

2. Taglioretti V, Fugassa MH, Sardella NH. Parasitic diversity found in coprolites of camelids during the Holocene. Parasitol Res 2015; 114: 2459-2464.

3. Gonçalves MLC, Araújo A, Ferreira LF. Human intestinal parasites in the past: new findings and a review. Mem Inst Oswaldo Cruz 2003; 98: 103-118.

4. Fugassa MH, Denegri GM, Sardella NH, Araújo A, Guichón RA, Martinez PA, Civalero MT, Aschero C. Paleoparasitological records in a canid coprolite from Patagonia, Argentina. J Parasitol 2006; 92: 1110-1113.

5. Beltrame MO, Fugassa MH, Sardella NH. First paleoparasitological results from late Holocene in Patagonian coprolites. J Parasitol 2010; 96: 648-651.

6. Mowlavi G, Makki M, Mobedi I, Araujo A, Aali A, Stollner T, Rezaeian M, Boenke N, Hassanpour G, Masoumian M. Paleoparasitological findings from rodent coprolites dated at $500 \mathrm{CE}$ Sassanid Era in archeological site of Chehrabad (Douzlakh), salt mine Northwestern Iran. Iran J Parasitol 2014; 9: 188-193.

7. Mowlavi G, Makki M, Heidari Z, Rezaeian M, Mohebali M, Araujo A, Boenke N, Aali A, Stollner T, Mobedi I. Macracanthorhynchus hirudinaceus eggs in canine coprolite from the Sasanian Era in Iran (4th/5th Century CE). Iran J Parasitol 2015; 10: 245249.

8. Nezamabadi M, Aali A, Stöllner T, Mashkour M, Le Bailly M. Pa- 
leoparasitological analysis of samples from the Chehrabad salt mine (Northwestern Iran). Int J Paleopathol 2013; 3: 229-233.

9. Sajjadi SMS, Foruzanfar F, Shirazi R, Baghestani S. Excavations at Shahr-i Sokhta. First Preliminary Report on the Excavations of the Graveyard, 1997-2000. Iran. 2003; 41: 21-97.

10. Milanesi C, Cresti M, Costantini L, Gallo M, Gallo G, Crognale S, Faleri C, Gradi A, Franco B. Spoilage of oat bran by sporogenic microorganisms revived from soil buried 4000 years ago in Iranian archaeological site. Int Biodeterior Biodegradation 2015; 104: 83-91.

11. Salvatori S, Tosi M. Shahr-i Sokhta revised sequence. South Asian Archaeol 2001; 1: 281-292.

12. Callen EO, Cameron TWM. A prehistoric diet revealed in coprolites. New Sci 1960; 8: 35-40.

13. Foreyt WJ. Veterinary parasitology reference manual. 5th ed. Iowa, USA. John Wiley \& Sons. 2013.

14. Soulsby EJL. Helminths, arthropods and protozoa of domesticated animals. London, UK. Bailliere Tindall \& Cassell. 1968.

15 Justine JL, Ferté H. Capillaria bovis (Nematoda, Capillariinae) parasite du Mouflon, du Daim et du Chevreuil en France. Bull Mus nain Hist Nat Paris 1989; 1: $79-96$ (in French).

16. Sianto L, Chame M, Silva CSP, Gonçalves MLC, Reinhard K, Fugassa M, Araújo A. Animal helminths in human archaeological remains: a review of zoonoses in the past. Rev Inst Med Trop S Paulo 2009; 51: 119-130.

17. Trachsel D, Deplazes P, Mathis A. Identification of taeniid eggs in the faeces from carnivores based on multiplex PCR using targets in mitochondrial DNA. Parasitology 2007; 134: 911-920.

18. Bouchet F, Harter S, Le Bailly M. The state of the art of paleoparasitological research in the Old World. Mem Inst Oswaldo Cruz 2003; 98: 95-101.

19. Alijani B, Ghohroudi M, Arabi N. Developing a climate model for Iran using GIS. Theor Appl Climatol 2008; 92: 103-112.

20. Mowlavi G, Mokhtarian K, Makki MS, Mobedi I, Masoumian M, Naseri R, Hoseini G, Nekouei P, Mas-Coma S. Dicrocoelium dendriticum found in a Bronze Age cemetery in western Iran in the pre-Persepolis period: the oldest Asian palaeofinding in the present human infection hottest spot region. Parasitol Int 2015; 64: 251-255.

21. Paknazhad N, Mowlavi G, Dupouy-Camet J, Esmaeili Jelodar M, Mobedi I, Makki M, Kia EB, Rezaeian M, Mohebali M, Sarlak S, Najafi F. Paleoparasitological evidence of pinworm (Enterobius vermicularis) infection in a female adolescent residing in ancient Tehran (Iran) 7000 years ago. Parasit Vectors 2016; 9: 33.

22. Nezamabadi M, Mashkour M, Aali A, Stöllner T, Le Bailly M. Identification of Taenia sp. in a natural human mummy (third century BC) from the Chehrabad salt mine in Iran. J Parasitol 2013; 99: 570-572.

23. Costantini L, Tosi M. The environment of Southern Sistan in the third millenium $\mathrm{BC}$, and its exploitation by the proto-urban Hilmand civilization. In Brice WC, The Environmental History of the Near and Middle East since the Last Ice Age. 1978, pp 165-183.

24. Le Bailly M, Bouchet F. Ancient dicrocoeliosis: occurrence, distribution and migration. Acta Trop 2010; 115: 175-180.

25. Justine JL, Ferté H. Redescription de Capillaria bovis (Schnyder, 1906) (Nematoda, Capillarinae). Bull Mus Natn Hist Nat Paris 1988; 10: 693-709.

26. Eslami AH, Nabavi L. Species of gastro-intestinal nematodes of sheep from Iran. Bull Soc Pathol Exot Filiales 1976; 69: 92-95.

27. Hoghooghi-Rad N, Maraghi S, Narenj-Zadeh A. Capillaria philippinensis infection in Khoozestan Province, Iran: case report. Am J Trop Med Hyg 1987; 37: 135-137. 
